\title{
Ovariectomy Enhances and Estrogen Replacement Inhibits the Activity of Bone Marrow Factors That Stimulate Prostaglandin Production in Cultured Mouse Calvariae
}

\author{
Hiroshi Kawaguchi, ${ }^{\star}$ Carol C. Pilbeam, ${ }^{\star}$ Socorro J. Vargas, ${ }^{5}$ Edward E. Morse, ${ }^{\ddagger}$ Joseph A. Lorenzo, ${ }^{\$}$ \\ and Lawrence G. Raisz* \\ ${ }^{*}$ Division of Endocrinology and Metabolism, Department of Medicine, and ${ }^{\ddagger}$ Division of Hematology/Blood Bank, Department of Lab \\ Medicine, University of Connecticut Health Center, Farmington, Connecticut 06030; and ${ }^{\S}$ Department of Medicine, Department of \\ Veterans Affairs Medical Center, Newington, Connecticut 06111
}

\begin{abstract}
To examine PG production in estrogen deficiency, we studied effects on cultured neonatal mouse calvariae of bone marrow supernatants (MSup) from sham-operated (SHAM), ovariectomized (OVX), or 17 $\beta$-estradiol $(\mathrm{OVX}+\mathrm{E})$-treated mice. MSups were obtained 3 wk after OVX when bone density had decreased significantly. 1060\% MSup increased medium PGE $_{2}$ and levels of mRNA for inducible and constitutive prostaglandin $\mathrm{G} / \mathrm{H}$ synthase (PGHS-2 and PGHS-1) and cytosolic phospholipase $A_{2}$ in calvarial cultures. OVX MSups had twofold greater effects on PGHS-2 and medium PGE ${ }_{2}$ than other MSups. IL-1 receptor antagonist and anti-IL-1 $\alpha$ neutralizing antibody decreased MSup-stimulated PGHS-2 mRNA and PGE 2 levels and diminished differences among OVX, sham-operated,

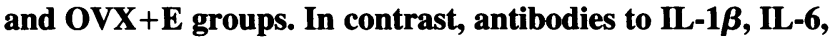
IL-11, and TNF $\alpha$ had little effect. There were no significant differences in IL-1 $\alpha$ concentrations or IL-1 $\alpha$ mRNA levels in MSups or marrow cells. PGHS-2 mRNA in freshly isolated tibiae from OVX mice was slightly greater than from sham-operated. We conclude that bone marrow factors can increase PG production through stimulation of PGHS-2; that OVX increases and estrogen decreases activity of these factors; and that $\mathrm{IL-1} \alpha$ activity, together with additional unknown factors, mediates the differential MSup effects. $(J$. Clin. Invest. 1995. 96:539-548.) Key words: cyclooxygenase - phospholipase $\mathbf{A}_{2} \cdot$ interleukin-1 cytokine $\cdot$ osteoporosis
\end{abstract}

\section{Introduction}

Although it is well established that estrogen deficiency plays a causal role in postmenopausal osteoporosis (1-3), the mecha-

A portion of this work was presented at the 16th annual meeting of the American Society for Bone and Mineral Research in Kansas City, MO, 9-13 September 1994.

Address correspondence to Lawrence G. Raisz, Division of Endocrinology and Metabolism, Department of Medicine, University of Connecticut Health Center, Farmington, CT 06030. Phone: 203-679-2129; FAX: 203-679-1258. H. Kawaguchi's present address is Department of Orthopaedic Surgery, Faculty of Medicine, Tokyo University, 7-3-1 Hongo, Bunkyo-ku, Tokyo 113, Japan.

Received for publication 23 September 1994 and accepted in revised form 30 March 1995.

J. Clin. Invest.

(c) The American Society for Clinical Investigation, Inc.

0021-9738/95/07/0539/10 \$2.00

Volume 96 , July $1995,539-548$ nism by which estrogen influences bone loss remains unclear. PGs are potent stimulators of bone resorption that may play a role in the bone loss of the estrogen-deficient state $(4,5)$. We previously reported that physiological concentrations of estradiol inhibited both bone resorption and PG production in cultured mouse calvariae (6). We also showed that PG production was increased in cultured calvariae from ovariectomized rats and was decreased by administration of estradiol in vivo (7). In vivo studies have shown that the resorptive response to ovariectomy was decreased by a nonsteroidal antiinflammatory drug, which is an inhibitor of PG synthesis $(8,9)$. A recent study has shown that the bone resorbing activity in bone marrow supernatants (MSups) ${ }^{1}$ was enhanced by ovariectomy and reversed by nonsteroidal antiinflammatory drugs (10).

PGs are produced in bone by many cells, especially osteoblasts $(11,12)$, and production is stimulated by a variety of cytokines that are derived from macrophages or hematopoietic cells $(13-18)$. Several cytokines produced by marrow cells, such as IL-1 $\alpha, \mathrm{IL}-1 \beta, \mathrm{IL}-6, \mathrm{IL}-11$, and TNF $\alpha$, have been implicated in the osteoporosis of estrogen deficiency (19-27). It is possible that the production and/or the activity of bone marrow cytokines may influence the bone loss of estrogen deficiency through effects on PG production.

The two major enzymes in PG synthesis are phospholipase $\mathrm{A}_{2}\left(\mathrm{PLA}_{2}\right)$, which releases AA from membrane fatty acids, and prostaglandin $\mathrm{G} / \mathrm{H}$ synthase (PGHS), or cyclooxygenase, which oxidizes $A A$ to $\mathrm{PGG}_{2}$ and reduces $\mathrm{PGG}_{2}$ to $\mathrm{PGH}_{2}$. Two genes for PGHS, constitutive PGHS (PGHS-1) and inducible PGHS (PGHS-2), have been identified $(28,29)$. These two enzymes are $\sim 60 \%$ identical in nucleic acid and amino acid composition, and have similar molecular masses of $\sim 70 \mathrm{kD}$. We have reported that several hormones and cytokines regulate PG production through the induction of PGHS, especially PGHS-2, in bone organ or osteoblastic cell cultures (30-33).

In the present study, we compared the ability of MSup from sham-operated (SHAM), ovariectomized (OVX), or ovariectomized and estrogen replaced $(\mathrm{OVX}+\mathrm{E})$ adult mice to stimulate PG synthesis in cultured 7-d-old mouse calvariae. We measured mRNA levels of PGHS-1, PGHS-2, and cytosolic PLA P $_{2}$ $\left(\mathrm{cPLA}_{2}\right)$, all of which may influence PG synthesis, as well as medium $\mathrm{PGE}_{2}$ levels. We found that MSup contains factors that

1. Abbreviations used in this paper: $\mathrm{BMD}$, bone mineral density; COL1A1, rat $\alpha 1$ (I) procollagen; cPLA $A_{2}$, cytosolic phospholipase $A_{2}$; GAPDH, glyceraldehyde-3-phosphate dehydrogenase; IL-1ra, IL-1 receptor antagonist; MMLV, Moloney murine leukemia virus; MSup, bone marrow supernatant; OVX, ovariectomized; OVX+E, OVX and estrogen replaced; PGHS, PG G/H synthase; $\mathrm{PLA}_{2}$, phospholipase $\mathrm{A}_{2} ; \mathrm{rm}$, recombinant murine; RT, reverse transcriptase; RT-PCR, reverse transcription PCR; SHAM, sham operated; sPLA 2 , secreted PLA 2 . 
increase mRNA levels of PGHS-1, PGHS-2, and CPLA $_{2}$, as well as $\mathrm{PGE}_{2}$ production. In addition, we demonstrated that the activity of these factors are regulated by endogenous estrogen.

\section{Methods}

Materials. Murine PGHS-1 cDNA was the gift of Drs. David DeWitt and William Smith (Michigan State University, East Lansing, MI). Murine $\mathrm{cPLA}_{2}$ cDNA was the gift of Dr. Carol Mase and Bill Lathrop (Miles Inc., West Haven, CT). Murine PGHS-2 cDNA was purchased from Oxford Biomedical Research Inc. (Oxford, MI). Murine IL-1a and IL- $1 \beta$ cDNA were provided by Dr. Peter Lomedico (HoffmannLaRoche Inc., Nutley, NJ). Murine IL-1 receptor antagonist (IL-1ra) cDNA was amplified by PCR using reverse-transcribed DNA from a murine macrophage cell line as a template. Rat $\alpha 1$ (I) procollagen (COL1A1) cDNA was constructed as described previously (34). Murine glyceraldehyde-3-phosphate dehydrogenase (GAPDH) cDNA was amplified by PCR using a mouse GAPDH control amplimer set from Clontech (Palo Alto, CA). Recombinant murine (rm) IL-1 $\alpha$, rmIL-1 $\beta$, anti-murine IL- $1 \alpha$, anti-murine IL- $1 \beta$, neutralizing antibodies to IL-6 and TNF $\alpha$, and nonimmune goat IgG were purchased from R\&D Systems (Minneapolis, MN). Anti-human IL-11 neutralizing antibody was a gift from Dr. Edward Alderman (Genetics Institute, Cambridge, MA). This antibody has previously been shown to neutralize murine IL-11 (26). Recombinant human IL-1ra was the gift of Dr. Ruth Eure (Synergen, Boulder, $\mathrm{CO}$ ). Slow release pellets for $17 \beta$-estradiol and placebo were purchased from Innovative Research of America (Toledo, $\mathrm{OH}$ ). Moloney murine leukemia virus reverse transcriptase (MMLV RT) and oligo (dT) 12-18 primer were obtained from Gibco BRL (Gaithersburg, MD). Taq polymerase was obtained from Perkin-Elmer Corp. (Norwalk, CT). Other chemicals were obtained from Sigma Chemical Co. (St. Louis, MO.)

Study protocol. Four experiments were conducted in 8-wk-old CD1 mice (Charles River Laboratories, Wilmington, MA) subjected to either dorsal ovariectomy or sham operation under general anesthesia The ovariectomized mice were implanted with either slow release (21 d) placebo pellets (OVX) or pellets containing $10 \mu \mathrm{g}$ of $17 \beta$-estradiol $(\mathrm{OVX}+\mathrm{E})$. Placebo pellets were implanted in SHAM mice. In experiments 1 and 2, pellets were implanted $1 \mathrm{wk}$ after the operation subcutaneously in the back under anesthesia. In experiments 3 and 4, pellets were implanted at the time of surgery. In all experiments, each group (SHAM, OVX, OVX+E) consisted of 12 to 13 mice. Mice were weighed and killed $3 \mathrm{wk}$ after surgery, following a protocol approved by the Institutional Animal Care Committee. Whole tibiae and femurs were excised from the mice, and their epiphyses were cut off at the same place to minimize variations in bone size. To obtain MSups, bone marrow was flushed carefully from both ends of bones with $1 \mathrm{ml}$ of BGJb medium (Gibco) containing $100 \mu \mathrm{g} / \mathrm{ml} \mathrm{L}$-ascorbic acid phosphate (Wako Chemical Co., Osaka, Japan) and $1 \mathrm{mg} / \mathrm{ml}$ BSA (radioimmunoassay grade). Flushed media were immediately centrifuged at low speed, and the supernatants from 12 to 13 mice in each group were pooled. The final volumes of MSups were $<10 \%$ different among the groups. MSups were analyzed for their ability to stimulate $\mathrm{PGE}_{2}$ production in cultured neonatal mouse calvariae and for cytokine levels as measured by specific ELISA. The number of cells were counted after diluting MSups 1:100 ( $\mathrm{vol} / \mathrm{vol})$ in $0.01 \mathrm{M}$ acetic acid to lyse red blood cells. Smears were made of the residual leukocytes and stained by Wright's staining method using Hemo-Tek 1000 (Miles Inc., Elkhart, IN) (35). Differential analysis of marrow cells was based on microscopic counting of 1,000 cells. Monocytes/macrophages were detected by nonspecific esterase staining using $\alpha$-naphthyl butyrate esterase (36). To extract marrow RNA, bone marrow was flushed with RNA extraction buffer and total RNA was extracted. The residual tibiae were washed with PBS and immediately put into RNA extraction buffer. The uterus was also quickly excised and weighed.

To validate the reverse transcription-PCR (RT-PCR) methodology used on freshly isolated bone or marrow, we did an additional experiment to induce greater PGHS-2 expression in vivo as a positive control. 11-wk-old CD-1 mice were injected with $2 \mathrm{mg}$ of bacterial endotoxin LPS, which is known to evoke a potent acute inflammatory response (37). Control mice were injected with equivalent amounts of vehicle. After $2 \mathrm{~h}$, animals were killed and RNA was extracted from bone marrow or residual tibia.

Bone mineral density ( $B M D$ ). BMD of SHAM, OVX, and $\mathrm{OVX}+\mathrm{E}$ mice were measured in a separate experiment. Four mice in each group were killed $3 \mathrm{wk}$ after surgery and whole tibiae were excised. BMD of the proximal one-third of the tibiae was measured by dual energy $x$-ray absorptiometry using DCS-600R (Aloka Co., Tokyo, Japan) (38), and the BMD of each animal was calculated as the mean of left and right tibiae. DCS-600R was modified for small animals based on DCS-600, a standard DEXA model to measure human radius BMD. We evaluated the precision of DCS-600R using an aluminum phantom, and the coefficient of variation was $<0.5 \%$. The operator was blinded to the treatment groups.

Neonatal mouse calvarial culture. 7- or 8-d-old CD-1 mice were killed and their calvariae were aseptically harvested and dissected free of suture tissue. Bones were precultured for $24 \mathrm{~h}$ in BGJb medium containing $100 \mu \mathrm{g} / \mathrm{ml} \mathrm{L}$-ascorbic acid phosphate, and $1 \mathrm{mg} / \mathrm{ml} \mathrm{BSA}$. They were cultured with or without MSup in 24-well dishes (Costar Corp., Cambridge, MA) on a rocking platform in a humidified atmosphere of $5 \% \mathrm{CO}_{2}$ at $37^{\circ} \mathrm{C}$ for $4 \mathrm{~h}$. This culture time was based on preliminary studies that showed IL-1, PTH, and other agents stimulated PGHS-2 mRNA levels maximally at $4 \mathrm{~h}$ in this system. Neutralizing antibodies, (IL-1ra), nonimmune goat IgG, and indomethacin were added $2 \mathrm{~h}$ before treatment and were present during the entire culture period.

RNA Extraction. Total RNA was extracted from neonatal mouse calvariae and adult mouse bone marrow by the method of Chomczynski and Sacchi (39). Briefly, six to eight half calvariae from neonatal mice or bone marrow flushed from tibiae and femurs of 12-13 adult mice per treatment group were homogenized in $4 \mathrm{M}$ guanidine isothiocyanate and extracted with phenol/chloroform-isoamyl alcohol (24:1). RNA was precipitated with isopropanol and washed with $80 \%$ ethanol. Total RNA from the residual adult mouse tibiae was prepared according to the procedure of Chirgwin et al. (40). Residual tibiae from 12-13 adult mice per treatment group were homogenized in a buffer of $4 \mathrm{M}$ guani-

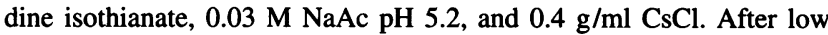
speed centrifugation at $10^{\circ} \mathrm{C}$, the supernatant was decanted, layered over a $\mathrm{CsCl}$ cushion ( $5.7 \mathrm{M} \mathrm{CsCl}, 0.03 \mathrm{M} \mathrm{NaAc}$ ) and centrifuged at $35 \mathrm{~K}$, $20^{\circ} \mathrm{C}$, for $12-16 \mathrm{~h}$. The pellet was washed with $70 \%$ alcohol, resuspended in water, and precipitated with $\mathrm{NaAc}$ and alcohol.

Northern blot analysis. After quantitation at $260 \mathrm{~nm}, 20-25 \mu \mathrm{g}$ of total RNA was fractionated on a $1 \%$ agarose $/ 2.2 \mathrm{M}$ formaldehyde gel and transferred to nylon membrane (Genescreen; New England Nuclear, Boston, MA) by positive pressure blotting (Posiblotter; Stratagene Inc., La Jolla, CA). After $3 \mathrm{~h}$ of prehybridization in a $50 \%$ formamide solution at $42^{\circ} \mathrm{C}$, filters were hybridized overnight in a similar solution in rotating cylinders (Hybridizer; Techne, Inc., Princeton, $\mathrm{NJ}$ ) at $42^{\circ} \mathrm{C}$ $\left(57^{\circ} \mathrm{C}\right.$ for $\left.\mathrm{COL} 1 \mathrm{~A} 1\right)$ with random primers and a $\left[{ }^{32} \mathrm{P}\right] \mathrm{dCTP}$-labeled cDNA probe for murine PGHS-1, PGHS-2, cPLA $_{2}$, IL-1 $\alpha$, IL-1 $\beta$, IL1ra, GAPDH, or COL1A1. Filters were washed and exposed to $x$-ray film with an intensifying screen at $-70^{\circ} \mathrm{C}$ for $2 \mathrm{~h}$ to $7 \mathrm{~d}$. Signals were quantitated by densitometry (Bio-Rad Laboratories, Richmond, CA). Filters were stripped by boiling in $0.1 \%$ SDS $+0.1 \times$ SSC between hybridizations.

$R T-P C R$. IL-1 $\alpha$, IL-1 $\beta$, and GAPDH mRNA levels in bone marrow cells were measured using PCR Amplimer sets (Clontech, Palo Alto, CA). PGHS-2 and PGHS-1 mRNA levels in bone cells and in residual tibiae were quantitated by competitive RT-PCR using a synthetic competitor for each. Competitive RT-PCR for PGHS-1 was done using primers and a competitor as reported previously $(31,33)$. The PCR products for PGHS-1 and competitor were $424 \mathrm{bp}$ and $844 \mathrm{bp}$, respectively. Oligonucleotide primers for IL-1 ra and PGHS-2 were synthesized by Oligos Etc. (Wilsonville, OR). Both the sense and antisense primers were designed to be interexonic to prevent amplification of contaminating genomic DNA. For IL-1 ra, the sense and antisense sequences were 5'-AAACCTGTGCCTGTCTATGG-3' and 5'-GAGTGAAGATGG- 
Table I. Body Weight, Uterus Weight, and the Number of Bone. Marrow Cells from SHAM, OVX, and OVX + E Mice

( $n=12-13$ in Each Group)

\begin{tabular}{lcccc}
\hline $\begin{array}{l}\text { Experiment } \\
\text { No. }\end{array}$ & 1 & 2 & 3 & 4 \\
\hline $\begin{array}{l}\text { Body wt (g) } \\
\text { SHAM }\end{array}$ & $30.8 \pm 0.5$ & $40.6 \pm 0.5$ & $31.6 \pm 0.3$ & $42.1 \pm 0.8$ \\
OVX & $31.7 \pm 0.7$ & $40.2 \pm 0.7$ & $32.3 \pm 0.7$ & $44.1 \pm 1.8$ \\
OVX+E & $30.6 \pm 0.6$ & $39.6 \pm 1.5$ & $29.9 \pm 0.3$ & $41.7 \pm 0.8$ \\
Uterus wt (mg) & & & \\
SHAM & $89.4 \pm 9.0$ & $114.7 \pm 7.9$ & $145.0 \pm 17.0$ & $119.5 \pm 12.9$ \\
OVX & $21.2 \pm 1.6 *$ & $24.5 \pm 1.1^{*}$ & $23.0 \pm 0.9 *$ & $21.0 \pm 0.6^{*}$ \\
OVX+E & $113.0 \pm 8.2$ & $135.3 \pm 11.0$ & $123.0 \pm 1.5$ & $110.9 \pm 13.2$ \\
Number of marrow cells $\left(\times 10^{6} / \mathrm{mm}^{2}\right)^{\ddagger}$ & & \\
SHAM & & & $28.6 \pm 2.4$ & $77.6 \pm 14.8$ \\
OVX & & & $38.8 \pm 3.8$ & $87.6 \pm 10.4$ \\
OVX+E & & & $31.0 \pm 1.2$ & $60.0 \pm 5.2$ \\
\end{tabular}

* Significant difference from SHAM: $P<0.01$. ${ }^{\ddagger}$ Cell number in tibia (experiment 3 ) and tibia + femur (experiment 4$)$.

TGTTTGGG-3', respectively. For PGHS-2, the sense and antisense sequences were 5'-TCAGCCAGGCAGCAAATCCTTG-3' and 5'TAGTCTCTCCTATGAGTATGAGTC-3', respectively. Competitor cDNA for PGHS-2 was made using a PCR construction kit (MIMIC; Clontech). The PCR products for PGHS-2 and competitor were 939 bp and $606 \mathrm{bp}$, respectively.

Reverse transcription and PCR were done as previously reported (31). Briefly, 2- $\mu \mathrm{g}$ aliquots of total RNA were reverse-transcribed using oligo (dT) as a primer (1.5 $\mu \mathrm{M}$ final concentration) in final $30 \mu \mathrm{l}$ of RT-solution. $5 \mu \mathrm{l}$ of RT-solution (containing cDNA from about $0.3 \mu \mathrm{g}$ of total RNA) was then amplified. For competitive RT-PCR, two aliquots of RT-solution ( $5 \mu \mathrm{l}$ and $10 \mu \mathrm{l}$ for PGHS-2; $2 \mu \mathrm{l}$ and $6 \mu \mathrm{l}$ for PGHS-1) were amplified to verify the accuracy of the method. The amplification cycle consisted of denaturation at $94^{\circ} \mathrm{C}$ for $45 \mathrm{~s}(3 \mathrm{~min}$ for the first cycle), annealing at $60^{\circ} \mathrm{C}$ for $45 \mathrm{~s}$, and extension at $72^{\circ} \mathrm{C}$ for $1.5 \mathrm{~min}$ ( $5 \mathrm{~min}$ for the last cycle). After 30 amplification cycles in the thermocycler (Gene Amplifier PCR System 9600; Perkin-Elmer Corp., Norwalk, CT), PCR products were analyzed by electrophoresis on a $5 \%$ polyacrylamide gel. Gels were stained with ethidium bromide, photographed, and dried onto cellulose paper. Radioactivity in each band was measured using a beta scope blot analyzer (Betagen Corp., Waltham, MA).

IL-1 Assays. Concentrations of IL- $1 \alpha$ and IL- $1 \beta$ in pooled MSup from each group were measured using specific ELISA kits from Genzyme Corp. (Cambridge, MA) and PerSeptive Diagnostics, Inc. (Cambridge, MA), respectively. The sensitivities of these assays were $15 \mathrm{pg} /$ $\mathrm{ml}$ and $10 \mathrm{pg} / \mathrm{ml}$, respectively.

$P G E_{2}$ Assays. Medium was removed from cultured bones and $\mathrm{PGE}_{2}$ accumulation was measured by radioimmunoassay as described previously (14).

Statistical analysis. Means of groups were compared by ANOVA and significance of differences was determined by post-hoc testing using Bonferonni's method.

\section{Results}

Table I shows the body weights, uterine weights, and the number of bone marrow cells in SHAM, OVX, and OVX $+\mathrm{E}$ mice from four separate experiments. There were no significant differences in mean body weight among the three groups in any experiment. Ovariectomy and estrogen replacement therapy appeared to be effective in all experiments since uterine weights
Table II. Type of Marrow Cells in the Tibiae and Femurs of SHAM, OVX, and $O V X+E$ Mice

\begin{tabular}{lccc}
\hline \multicolumn{1}{c}{ Groups } & SHAM & OVX & OVX+E \\
\hline & $\%$ & $\%$ & $\%$ \\
Lymphocytes & $30.7 \pm 2.5^{*}$ & $40.1 \pm 2.1^{\ddagger}$ & $39.4 \pm 3.4$ \\
Granulocytes & $48.6 \pm 4.7$ & $31.5 \pm 1.5^{\ddagger}$ & $39.0 \pm 5.0$ \\
$\begin{array}{l}\text { Erythrocytes } \\
\text { Nonspecific } \\
\text { esterase positive }\end{array}$ & $16.4 \pm 3.1$ & $16.2 \pm 3.4$ & $14.8 \pm 2.7$ \\
(monocytes/macrophages) & $3.2 \pm 0.1$ & $3.1 \pm 0.2$ & $3.7 \pm 0.8$ \\
\hline
\end{tabular}

* Data are means $\pm \mathrm{SE}$ for four to six samples from experiments 3 and 4 in Table I. ${ }^{\ddagger}$ Significant difference from SHAM: $P<0.01$.

in the OVX groups were much lower (four to six times) than in either of the other two groups. Marrow cell counts were performed in experiments 3 and 4 (Table I). The differences in the number of marrow cells among the three groups were not significant. However, the percentage of granulocytes was significantly decreased and the percentage of lymphocytes was significantly increased in OVX mice compared with SHAM (Table II). The number of monocytes and macrophages in the marrow, as identified by nonspecific esterase staining, was not significantly different among the three groups.

BMD of the proximal one-third of the tibiae was measured in a separate experiment at $3 \mathrm{wk}$ after surgery. OVX mice showed a significant $(20 \%)$ decrease in BMD compared with SHAM and OVX $+E$ mice, indicating that bone loss due to estrogen deficiency had occurred at $3 \mathrm{wk}$, and that this bone loss was prevented by estrogen replacement (Table III).

MSup from these four separate experiments was used to treat cultures of neonatal mouse calvariae. Table IV gives treated/control ratios for PGHS-2, PGHS-1, and cPLA A $_{2}$ mNA levels normalized to GAPDH mRNA levels, as well as medium $\mathrm{PGE}_{2}$ levels, in neonatal mouse calvarial cultures that were treated with either control medium, 20\% MSup, or $40 \%$ MSup. Using MSups from experiment numbers $1,2,3$, and 4, we did $1,3,3$, and 4 sets of neonatal mouse calvarial cultures, respectively. Each set used MSups from the three treatment groups, with $n=4-6$ calvariae in each group. The data in Table IV are from the first culture from each of the four experiments. Addition of MSup from any treatment group to the calvarial cultures increased steady-state PGHS-2 and -1 mRNA levels as well as medium $\mathrm{PGE}_{2}$ compared with calvaria cultured without

Table III. BMD of the Proximal One-third of the Tibiae in SHAM, $O V X$, and $O V X+E$ Mice

\begin{tabular}{lccccc}
\hline & \multicolumn{4}{c}{ BMD $\left(\mathrm{mg} / \mathrm{cm}^{2}\right)$} \\
\cline { 2 - 5 } \multicolumn{1}{c}{ Mouse } & 1 & 2 & 3 & 4 & Mean \pm SM \\
\hline SHAM & 27.9 & 30.7 & 28.5 & 29.2 & $29.1 \pm 0.6$ \\
OVX & 25.7 & 25.9 & 25.5 & 24.2 & $25.3 \pm 0.4^{*}$ \\
OVX+E & 28.3 & 26.0 & 31.6 & 35.1 & $30.3 \pm 2.0$ \\
\hline
\end{tabular}

Data are expressed as the average of the left and right tibial BMD for four mice in each group. ${ }^{*}$ Significant difference from SHAM: $P$ $<0.01$. 
Table IV. PGHS-2, PGHS-1, and cPLA $A_{2}$ mRNA Levels Expressed as Treated/Control Ratios, and Medium PGE ${ }_{2}$ Concentrations in Neonatal Mouse Calvarial Cultures Treated with MSup from SHAM, OVX, and OVX+E Adult Mice*

\begin{tabular}{|c|c|c|c|c|}
\hline Experiment No. & 1 & 2 & 3 & 4 \\
\hline \multicolumn{5}{|c|}{ PGHS-2 mRNA/GAPDH mRNA (T/C) } \\
\hline Control & 1.0 & 1.0 & 1.0 & 1.0 \\
\hline SHAM & 5.4 & 1.7 & 2.5 & 3.7 \\
\hline ovX & 15.2 & 3.1 & 7.6 & 5.6 \\
\hline OVX+E & 6.8 & 1.9 & 1.6 & 3.8 \\
\hline \multicolumn{5}{|c|}{ PGHS-1 mRNA/GAPDH mRNA (T/C) } \\
\hline Control & 1.0 & 1.0 & 1.0 & 1.0 \\
\hline SHAM & 2.5 & 1.8 & 1.5 & 2.1 \\
\hline ovx & 2.8 & 1.6 & 2.0 & 2.2 \\
\hline OVX+E & 3.0 & 1.7 & 2.2 & 2.3 \\
\hline \multicolumn{5}{|c|}{ cPLA $_{2}$ mRNA/GAPDH mRNA (T/C) } \\
\hline Control & 1.0 & 1.0 & 1.0 & 1.0 \\
\hline SHAM & 1.4 & 1.1 & 1.4 & 2.5 \\
\hline OVX & 2.0 & 1.2 & 1.7 & 3.0 \\
\hline $\mathrm{OVX}+\mathrm{E}$ & 0.9 & 1.1 & 1.3 & 2.7 \\
\hline \multicolumn{5}{|c|}{ Medium $\mathrm{PGE}_{2}(\mathrm{nM})$} \\
\hline Control & $2.6 \pm 0.9$ & $3.7 \pm 1.3$ & $2.2 \pm 0.6$ & $2.8 \pm 0.8$ \\
\hline SHAM & $4.3 \pm 0.8$ & $6.3 \pm 1.7$ & $6.1 \pm 1.4^{\ddagger}$ & $10.9 \pm 2.4^{8}$ \\
\hline OVX & $10.6 \pm 1.3^{8 \|}$ & $30.9 \pm 7.7^{8 \|}$ & $20.5 \pm 3.2^{\S \|}$ & $11.7 \pm 2.1^{8}$ \\
\hline $\mathrm{OVX}+\mathrm{E}$ & $4.8 \pm 0.8$ & $17.5 \pm 6.4^{\dagger}$ & $6.9 \pm 2.2^{\dagger}$ & $7.9 \pm 1.2^{8}$ \\
\hline
\end{tabular}

* 7-d-old mouse calvariae were treated with control medium or a mixture of MSup and control medium. $40 \%$ (experiment 1 ) or $20 \%$ (experiments 2,3 , and 4) of MSup were used. ${ }^{\ddagger}$ Significant difference from control: $P<0.05 ;{ }^{\S} P$ $<0.01$. "Significant difference from SHAM: $P<0.01$. T/C, treated/control ratios.

MSup (Table IV). Fig. 1 shows the mean \pm SEM of treated/ control ratios for the mRNA levels of the three enzymes and medium $\mathrm{PGE}_{2}$ levels from all of the calvarial cultures that were treated with $20 \%$ MSup from three separate experiments (a total of 10 cultures from experiment numbers 2, 3, and 4). MSup from OVX mice had the greatest stimulatory activity for PGHS-2 mRNA and medium PGE $_{2}$ levels (about fivefold) compared to MSup from SHAM or OVX+E mice (two- to threefold). PGHS-1 and cPLA I $_{2}$ mRA levels were increased by about twofold by MSup, but there were no significant differences among the groups. Medium $\mathrm{PGE}_{2}$ levels in the calvariae cultures correlated with PGHS-2, but not with PGHS-1 or cPLA $_{2}$, mRNA levels. PGE 2 levels in MSup were below the detection limit of the assay ( $<0.1 \mathrm{nM}$, data not shown). Therefore, $\mathrm{PGE}_{2}$ in the medium of calvaria cultures resulted from de novo production by the cultured bones.

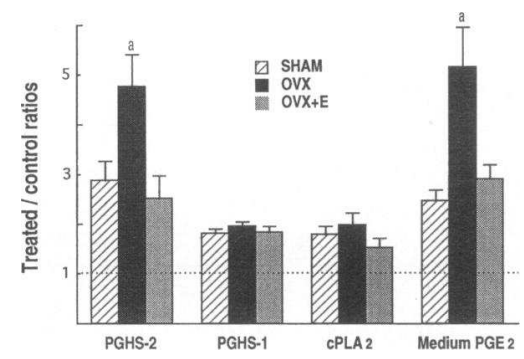

Figure 1. Effects of MSup (20\%) from SHAM, OVX, OVX+E mice on PGHS-2, PGHS1 , and cPLA $\mathrm{A}_{2}$ mRNA levels and medium $\mathrm{PGE}_{2}$ levels in neonatal mouse calvarial cultures. MSups were taken from 11-wkold mice at $3 \mathrm{wk}$ after the surgery. Parietal bones

from 7-d-old mice were precultured for $24 \mathrm{~h}$ and cultured for $4 \mathrm{~h}$ with and without $20 \%$ MSup. Treated/control ratios were pooled from 10 sets of cultures treated with $20 \%$ MSup from three separate experiments (experiments 2,3 , and 4 ). ${ }^{*}$ Significant difference from SHAM: $P$ $<0.01$.

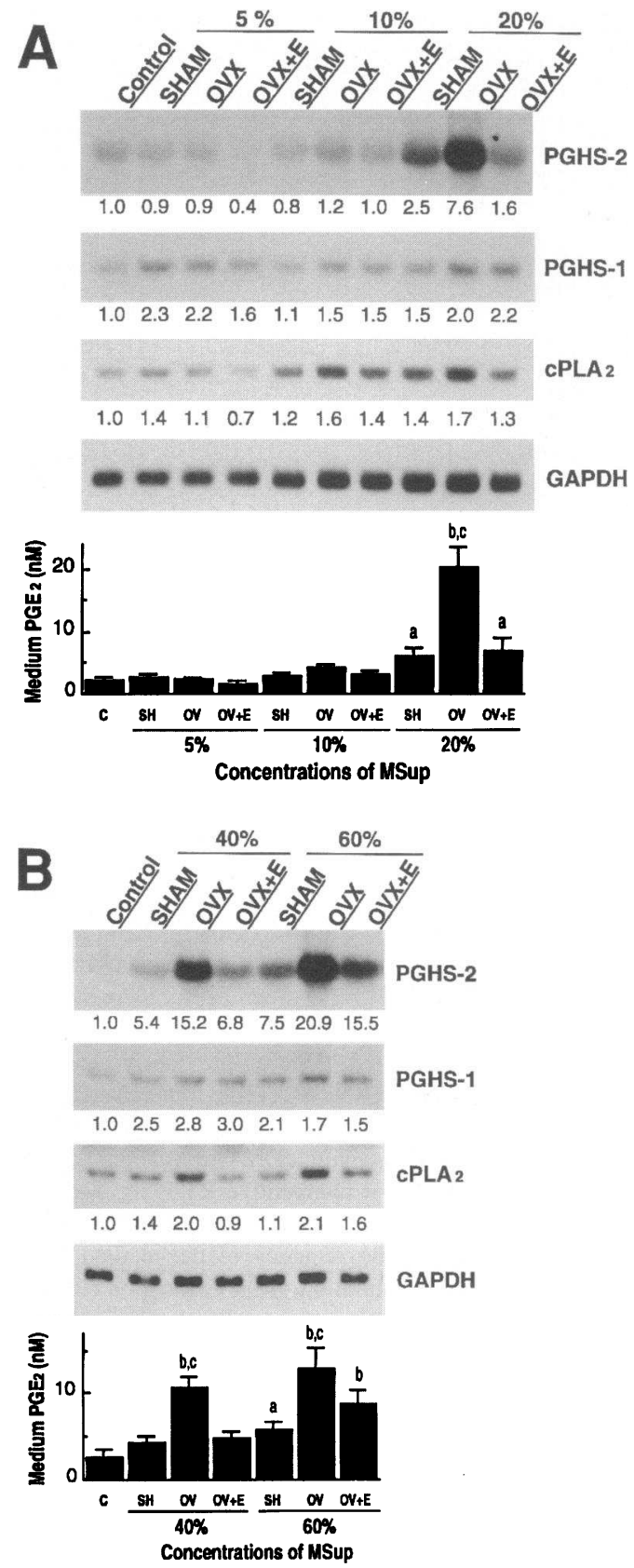

Figure 2. Dose-response of the effects of MSup from SHAM, OVX, and OVX+E mice on PGHS-2, PGHS-1, and CPLA 2 mRNA levels and medium $\mathrm{PGE}_{2}$ levels in neonatal mouse calvarial culture. Parietal bones from 7-d-old mice were precultured for $24 \mathrm{~h}$ and cultured for $4 \mathrm{~h}$ with 5-60\% MSup. Total RNA was extracted and $25 \mu \mathrm{g}$ of RNA was fractionated on a $1 \%$ agarose gel and transferred to nylon filters. For $A$ and $B$, MSups from different experiments were used (experiment 3 and experiment 1, respectively). The number under each band is the treated/ control ratio of the intensity of each band normalized to that of GAPDH measured by densitometry. Significant difference from control: ${ }^{a} P<$ $0.05,{ }^{b} P<0.01$. Significant difference from SHAM in each concentration: ${ }^{\mathrm{c}} P<0.01$.

Fig. 2 shows the dose response for the effects of $5-60 \%$ MSup from the three groups on PGHS-2, PGHS-1, and cPLA mRNA levels and medium PGE 2 levels. For Fig. 2, $A$ and $B$, MSups from different experiments were used (experiment 3 and experiment 1 , respectively). In both, MSup stimulated PGHS-2 

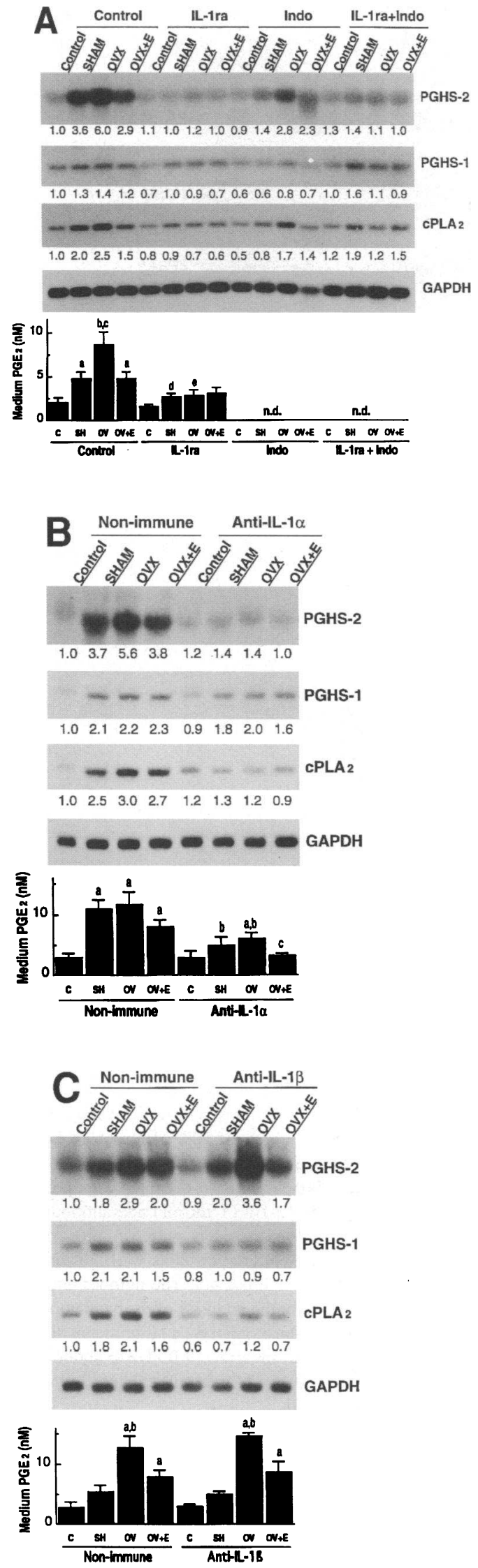

Figure 3. Effects of IL-1ra and indomethacin (A), anti-IL- $1 \alpha$ antibody $(B)$, and anti-IL- $\beta(C)$ on MSup-stimulated PGHS-2, PGHS-1, and $\mathrm{cPLA}_{2}$ mRNA levels and medium $\mathrm{PGE}_{2}$ levels in neonatal mouse calvarial cultures. Parietal bones from 7-d-old mice were precultured for 24
mRNA and medium $\mathrm{PGE}_{2}$ levels dose dependently. The effects of MSup from OVX mice were greater than those from SHAM or OVX $+\mathrm{E}$ animals at MSup concentrations $>10 \%$ for PGHS2 and $>20 \%$ for medium PGE 2 levels. PGHS-1 and CPLA $_{2}$ mRNA levels were stimulated by MSups to a lesser extent than PGHS- 2 mRNA or PGE $_{2}$ levels. However, these responses varied little among the three groups and were not changed by increasing MSup concentrations.

We examined the ability of neutralizing antibodies and antagonists of cytokines and PGHS to inhibit the effects of MSups on PG production by cultured calvariae. These agents were added to calvariae cultured with $20 \%$ MSup from SHAM, OVX, and $\mathrm{OVX}+\mathrm{E}$ mice. We have previously demonstrated that IL1ra $(1 \mu \mathrm{g} / \mathrm{ml})$ abrogated the effects of IL- $1 \alpha(10 \mathrm{ng} / \mathrm{ml})$ on $\mathrm{PGE}_{2}$ production in neonatal mouse calvariae (41). In the current experiments we found that IL-1ra $(1 \mu \mathrm{g} / \mathrm{ml})$ blocked the ability of MSup to increase PGHS-2 mRNA and medium PGE $_{2}$ levels (Fig. $3 A$ ). IL-1ra also markedly diminished the differences in PGHS-2 mRNA and medium PGE $_{2}$ levels among the three groups.

We previously showed that $40-80 \%$ of the stimulatory effects of IL- $1 \alpha$ on PGHS- 2 in this neonatal mouse calvarial system may be due to the induction of PGHS-2 mRNA by endogenous PGs or autoamplification (31). To determine if autoamplification was involved in the responses to MSups, we added indomethacin $\left(10^{-6} \mathrm{M}\right)$ to cultures that were treated with or without IL-1ra (Fig. $3 A$ ). Indomethacin alone abrogated $\mathrm{PGE}_{2}$ production and decreased MSup-stimulated increases in mRNA levels of the enzymes. This result suggests that the ability of MSup to stimulate PG in calvarial cultures is partially due to autoamplification. However, the ability of MSup from OVX animals to stimulate a larger increase in PGHS-2 mRNA levels compared to MSup from SHAM and OVX+E groups was maintained in the presence of indomethacin.

Anti-murine IL-1 $\alpha$ neutralizing antibody $(10 \mu \mathrm{g} / \mathrm{ml})$ also decreased MSup-induced PGHS-2 and cPLA ${ }_{2}$ mRNA levels to control levels, and decreased medium $\mathrm{PGE}_{2}$ levels in all the groups significantly (Fig. $3 \mathrm{~B}$ ). PGHS-1 mRNA levels were less inhibited by anti-IL- $1 \alpha$ antibody. Anti-murine IL- $1 \beta$ neutralizing antibody $(10 \mu \mathrm{g} / \mathrm{ml})$ did not decrease the effects of MSup on PGHS- 2 mRNA or medium PGE $_{2}$, but did reduce

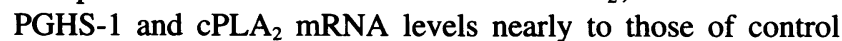
cultures (Fig. $3 C$ ). Neutralizing antibodies against murine IL6 , human IL-11, or murine TNF $\alpha$ (each at $10 \mu \mathrm{g} / \mathrm{ml}$ ) did not alter MSup-induced effects on enzyme mRNA levels or medium PGE $_{2}$ levels (Fig. 4, $A$ and $B$ ).

We investigated the cross-reactivity of the neutralizing ef-

$\mathrm{h}$ and cultured for $4 \mathrm{~h}$ with $20 \%$ MSup. IL- $1 \mathrm{ra}(1 \mu \mathrm{g} / \mathrm{ml})$, indomethacin $(10 \mu \mathrm{M})$, antibodies against mouse IL- $1 \alpha$ and IL- $\beta$ (both $10 \mu \mathrm{g} / \mathrm{ml}$ ), and nonimmune goat $\operatorname{IgG}(10 \mu \mathrm{g} / \mathrm{ml})$ were added $2 \mathrm{~h}$ before treatment with MSup and were present during the entire culture periods. Total RNA was extracted and 20-25 $\mu$ g of total RNA was fractionated on a $1 \%$ agarose gel. The number under each band is the treated/control ratio of the intensity of the band normalized to that of GAPDH measured by densitometry. $(A)$ Significant difference from control: ${ }^{a} P<0.01$. Significant difference from SHAM: ${ }^{\mathrm{c}} P<0.05$. Significant effect of IL-1 ra: ${ }^{\mathrm{d}} P<0.01,{ }^{\mathrm{e}} P<0.05$. (B) Significant difference from control: ${ }^{\mathrm{a}} P<0.01$. Significant effect of anti-IL-1 $\alpha$ antibody: ${ }^{\mathrm{b}} P<0.05,{ }^{\mathrm{c}} P$ $<0.01$. ( $C$ ) Significant difference from control: ${ }^{a} P<0.01$. Significant difference from SHAM: ${ }^{\mathrm{b}} P<0.01$. 


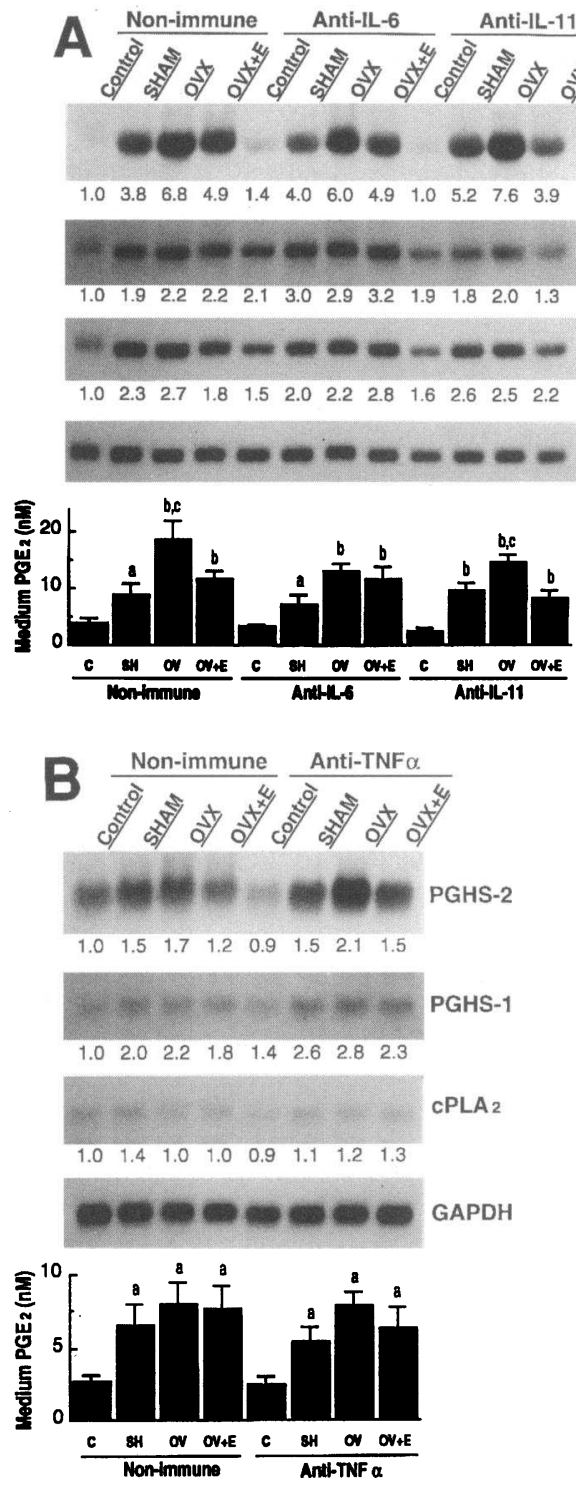

Figure 4. Effects of anti-IL-6 antibody and anti-IL-11 antibody $(A)$ and anti-TNF- $\alpha$ antibody ( $B$ ) on MSup-stimulated PGHS-2, PGHS-1, and $\mathrm{cPLA}_{2}$ mRNA levels and medium $\mathrm{PGE}_{2}$ levels in neonatal mouse calvarial cultures. Parietal bones from 7-d-old mice were precultured for 24 $\mathrm{h}$ and cultured for $4 \mathrm{~h}$ with $20 \%$ MSup. Antibodies and nonimmune goat IgG (all $10 \mu \mathrm{g} / \mathrm{ml})$ were added $2 \mathrm{~h}$ before treatment with MSup and were present during the entire culture periods as well. $20 \mu \mathrm{g}$ of total RNA was fractionated on a $1 \%$ agarose gel. The number under each band is the treated/control ratio of the intensity of the band normalized to that of GAPDH measured by densitometry. Significant difference from control: ${ }^{\mathrm{a}} P<0.05,{ }^{\mathrm{b}} P<0.01$. Significant difference from SHAM: ${ }^{\mathrm{c}} P<0.01$

fects of IL-1 ra, anti-IL- $1 \alpha$, and anti-IL- $1 \beta$ antibodies in murine neonatal calvaria cultures (Fig. $5 A$ ). Both recombinant murine IL- $1 \alpha$ and IL- $1 \beta$ (each at $100 \mathrm{pg} / \mathrm{ml}$ ) stimulated PGHS-2 and

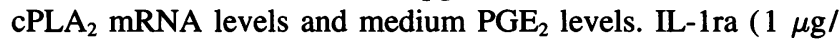
$\mathrm{ml}$ ) blocked the stimulation by both IL- $1 \alpha$ and IL- $1 \beta$, while anti-IL- $1 \alpha$ and anti-IL- $1 \beta$ blocked the effects of IL- $1 \alpha$ and IL- $1 \beta$, respectively, without cross-reactivity. Thus, our results suggest that IL- $1 \alpha$, but not IL- $1 \beta$, is one of the factors in MSup that stimulates PG production in bone cells through the induction of PGHS- 2 and that the activity of MSup IL- $1 \alpha$ on calvaria

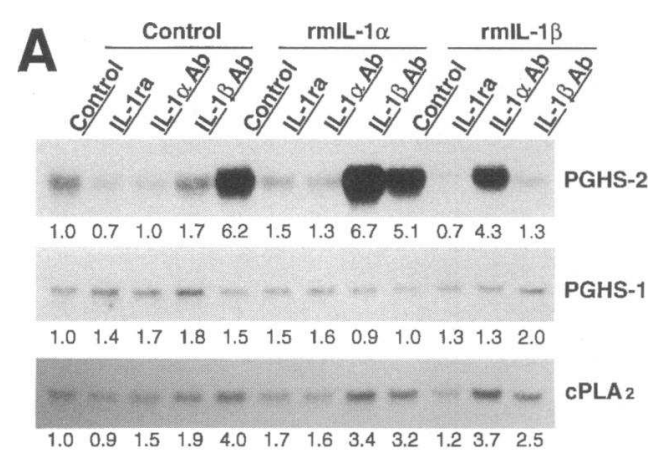

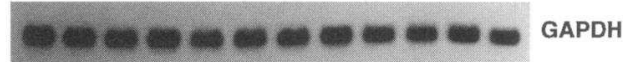
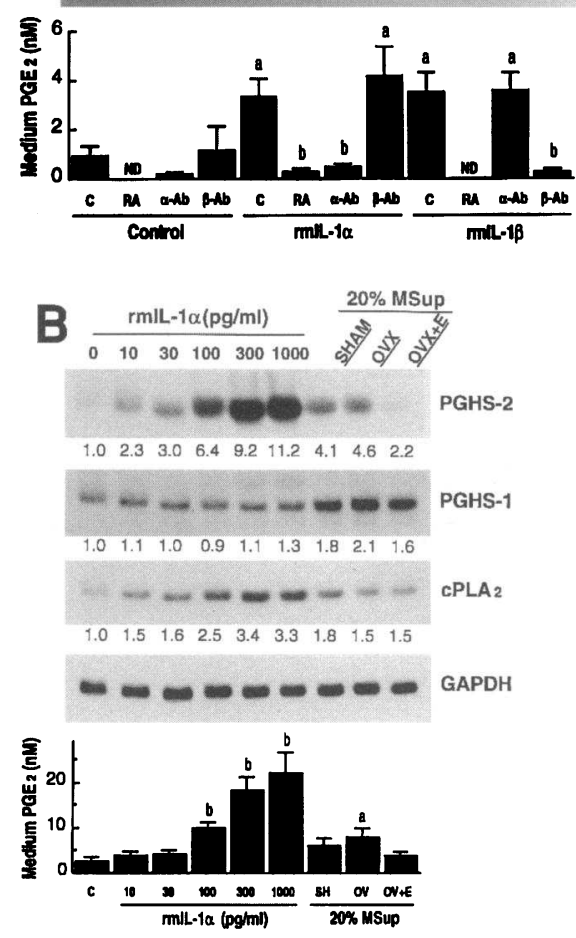

Figure 5. (A) Cross-reactivity of the neutralizing effects of IL-1ra, antiIL- $1 \alpha$ antibody, and anti-IL- $1 \beta$ antibody on IL- $1 \alpha$ or IL- $1 \beta$-stimulated PGHS-2, PGHS-1, and CPLA $_{2}$ mRNA levels and medium PGE Pevels $_{2}$ in neonatal mouse calvarial cultures. $(B)$ Dose response of the effects of exogenous rmIL- $1 \alpha$ compared to effects of $20 \%$ MSup on PGHS-2, PGHS-1, and cPLA ${ }_{2}$ mRNA levels and medium PGE $_{2}$ levels in neonatal mouse calvarial cultures. Parietal bones from 7-d-old mice were precultured for $24 \mathrm{~h}$ and cultured for $4 \mathrm{~h}$. IL-1ra $(1 \mu \mathrm{g} / \mathrm{ml})$ and antibodies (both $10 \mu \mathrm{g} / \mathrm{ml}$ ) were added $2 \mathrm{~h}$ before treatment with MSup or rmIL1 and were present during the entire culture period as well. $20 \mu \mathrm{g}$ of total RNA was fractionated on a $1 \%$ agarose gel. The number under each band is the treated/control ratio of the intensity of the band normalized to that of GAPDH measured by densitometry. $(A)$ Significant difference from control: ${ }^{a} P<0.01$. Significant effect of IL-1ra or antibodies: ${ }^{\mathrm{b}} P<0.01$. ND, not detectable $(<0.1 \mathrm{nM})$. (B) Significant difference from control: ${ }^{\mathrm{a}} P<0.05,{ }^{\mathrm{b}} P<0.01$.

cultures is enhanced by estrogen deficiency and decreased by estrogen replacement.

To estimate the concentration of $\mathrm{IL}-1 \alpha$ that produced effects similar to those seen with MSup, we generated a dose-response curve for rmIL-1 $\alpha$ in the calvarial cultures. Levels of rmIL-1 $\alpha$ between 10 and $100 \mathrm{pg} / \mathrm{ml}$ produced effects on PGHS-2 and cPLA $_{2}$ mRNA levels and medium PGE $_{2}$ levels that were equivalent to those seen with $20 \%$ MSup (Fig. 5 B ). Interestingly, 
Table V. Concentrations of IL-1 $\alpha$ and IL-1 $\beta$ in MSup from Tibiae and Femurs of SHAM, OVX, and OVX+E Mice Measured by ELISA

\begin{tabular}{lrrrr}
\hline Experiment No. & 2 & 3 & 4 & Mean \pm SE \\
\hline IL-1 $\alpha(\mathrm{pg} / \mathrm{ml})$ & & & & \\
$\quad$ SHAM & 86.1 & 121.4 & 147.6 & $118.4 \pm 17.8$ \\
OVX & 107.9 & 132.4 & 107.6 & $116.0 \pm 8.2$ \\
OVX+E & 115.8 & 108.3 & 119.0 & $114.4 \pm 3.2$ \\
IL-1 $\beta(\mathrm{pg} / \mathrm{ml})$ & & & & \\
SHAM & 6.6 & 7.3 & 8.6 & $6.5 \pm 0.6$ \\
OVX & 8.9 & 7.6 & 6.5 & $7.7 \pm 0.7$ \\
OVX+E & 6.8 & 7.1 & 4.9 & $6.3 \pm 0.7$ \\
& & & & \\
\hline
\end{tabular}

* Each measurement represents the combined MSups from 12-13 mice.

rmIL- $1 \alpha$ could not replicate the effects of $20 \%$ MSup on PGHS$1 \mathrm{mRNA}$ levels even at the highest concentration, suggesting that the induction of PGHS-1 is mediated by factors other than IL-1 $\alpha$.

To study whether the production of IL- $1 \alpha$ by marrow cells is regulated by OVX and estrogen in vivo, we measured the concentration of IL- $1 \alpha$ and IL- $1 \beta$ in MSup by specific ELISAs. As shown in Table V, $20 \%$ MSup should have $\sim 20 \mathrm{pg} / \mathrm{ml}$ of IL- $1 \alpha$ which is in the range necessary to produce equivalent effects of rmIL- $1 \alpha$ as shown in Fig. $5 B$. However, there was no difference in the IL- $1 \alpha$ concentration among MSups from SHAM, OVX, and OVX $+\mathrm{E}$ mice. IL- $1 \beta$ concentrations were below the lower limit of the assay $(10 \mathrm{pg} / \mathrm{ml})$ in all the groups. In addition, steady-state mRNA levels of IL- $1 \alpha$ and IL- $1 \beta$ in marrow cells from SHAM, OVX, and OVX $+\mathrm{E}$ mice measured by Northern blot analysis did not differ among the groups (Fig. $6 A$ ). To study IL- $1 \alpha$ and IL-1 $\beta$ mRNA levels in marrow cells more precisely, RT-PCR was done and the amplified products were normalized to those of GAPDH. As a positive control for validating this method, RNA was extracted from marrow cells of mice that had been injected in vivo with LPS $(2 \mathrm{mg}) 2 \mathrm{~h}$ before they were killed. Although we could easily detect increases in both IL- $1 \alpha$ and $\beta$ mRNA levels after LPS injection, we found no differences in these levels in marrow cells from SHAM, OVX, and OVX+E mice (Fig. $6 B$ ).

It is possible that differences in levels of endogenous IL1 ra could produce the effects we detected. This protein inhibits IL-1 action by competing with IL-1 for binding to receptors without transducing a signal $(41,42)$. However, mRNA levels for IL-1ra did not vary among the three groups either by Northern blotting or RT-PCR (Fig. $6 A$ and $B$ ). In contrast, in vivo LPS injection markedly stimulated IL-1ra mRNA levels determined by RT-PCR.

We also examined RNA extracted from freshly isolated tibiae after the marrow was flushed to see if PGHS-2 mRNA levels were regulated by in vivo estrogen deficiency or replacement. PGHS-2 mRNA was not detected in residual tibiae by Northern analysis (data not shown). To detect small amounts and small changes in levels of PGHS-2 mRNA, we used a competitive RT-PCR method (Fig. 7 B). Quantitative results are shown in Table VI. This method was found to be accurate and sensitive in our previous studies $(31,33)$. To validate the method further, we showed that PGHS-2 mRNA levels from $10 \mu$ l RT solution were almost double the values of those from $5 \mu$ l RT solution in each group and that in vivo LPS injection increased PGHS-
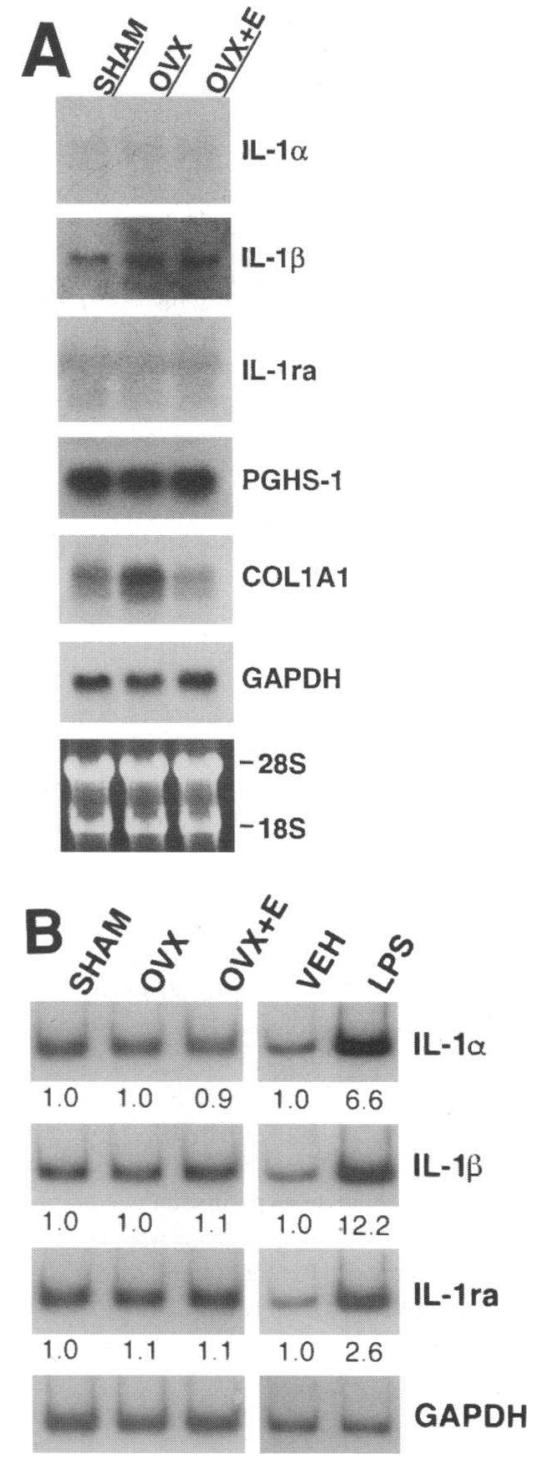

Figure 6. (A) Northern blot analysis for the indicated factors in bone marrow cells of SHAM, $\mathrm{OVX}$, and $\mathrm{OVX}+\mathrm{E}$ mice. (B) RT-PCR for IL- $1 \alpha$, IL- $\beta$, and IL-1ra in bone marrow cells of SHAM, OVX, and $\mathrm{OVX}+\mathrm{E}$ mice. Bone marrow of SHAM, OVX, and $\mathrm{OVX}+\mathrm{E}$ mice at 3 wk after the operation was flushed out with $4 \mathrm{M}$ guanidine isothiocyanate and total RNA was extracted following the procedure of Chomczynski et al. (36). (A) $25 \mu \mathrm{g}$ of total RNA was fractionated on a $1 \%$ agarose gel, transferred to a nylon membrane, and hybridized sequentially. (B) 2 $\mu \mathrm{g}$ aliquots of total RNA were reverse transcribed in final $30 \mu$ l of RT-solution. $5 \mu \mathrm{l}$ of RT-solution was then amplified by PCR. As a positive control, LPS ( $2 \mathrm{mg}$ ) or vehicle was injected into 11wk-old mice. After $2 \mathrm{~h}$, mice were killed and total RNA was extracted. The numbers under each band are treated/control ratios of the intensity of each band measured by densitometry normalized to that of GAPDH.
2 mRNA levels 15.7-fold and PGHS-1 mRNA levels 2-fold compared with vehicle injection (Fig. $7 \mathrm{~B}$ ). With this method, PGHS-2 mRNA levels in residual tibiae of OVX mice showed a small but significant increase compared to those from SHAM mice. However, in contrast to the effects of MSups on calvarial cultures, PGHS- 2 mRNA levels in OVX+E mice were not different from those of OVX mice. PGHS-1 mRNA levels in tibiae were not regulated by in vivo estrogen status when measured either by Northern blotting (Fig. $7 A$ ) or competitive RT-PCR (Fig. $7 B$ and Table VI).

COL1A1 mRNA was examined both in bone marrow cells (Fig. $6 \mathrm{~A}$ ) and in residual tibiae (Fig. $7 \mathrm{~A}$ ) by Northern blot analysis. Tissues from OVX mice had COL1A1 mRNA levels higher than those from SHAM and OVX+E mice. We could

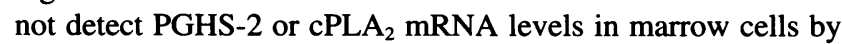
Northern blotting (data not shown) while PGHS-1 mRNA was detected but did not vary among the three groups (Fig. $6 \mathrm{~A}$ ).

\section{Discussion}

In this study we found that MSups from OVX, SHAM, and $\mathrm{OVX}+\mathrm{E}$ mice stimulated PG production in calvarial cultures 

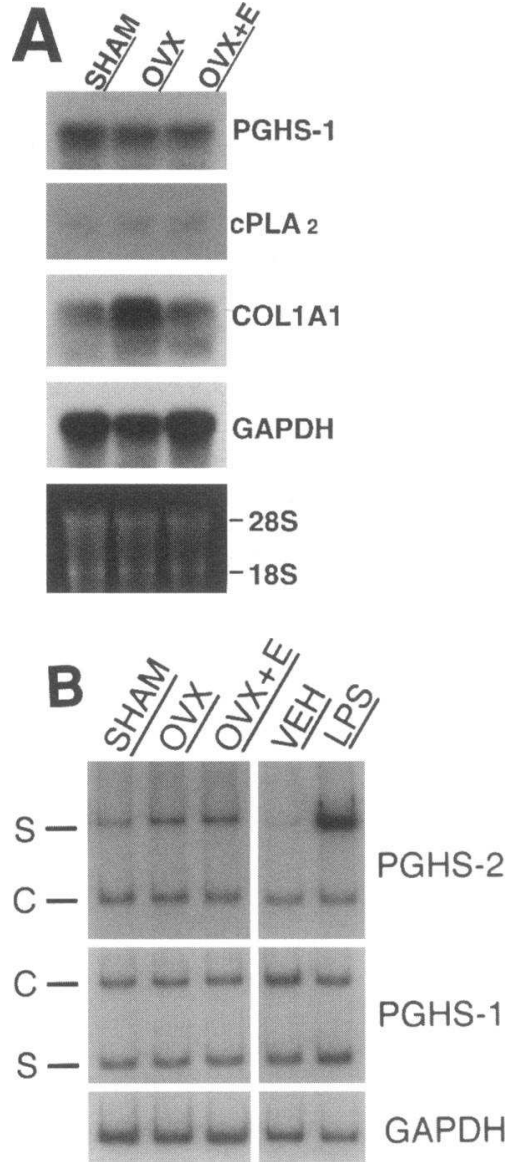

amount of synthetic competitor in two separate experiments (quantitative data shown in Table VI). RNA of LPS-injected mice was used as a positive control. This figure shows representative autoradiographs (5$\mu \mathrm{l}$ aliquot for PGHS-2 and 6- $\mu \mathrm{l}$ aliquot for PGHS-1, both from experiment 3). C, competitor; S, sample.

principally through their ability to induce PGHS-2. Furthermore, we demonstrated that the ability to induce PGHS-2 and PG production in bone cultures was increased in MSups from OVX mice and could be reversed by in vivo estrogen replacement.

Several cytokines have been implicated as factors that mediate postmenopausal bone loss (19-27). IL-1, a proinflammatory cytokine, is principally produced by activated macrophages (43) but can also be synthesized by bone cells and adjacent hematopoietic cells $(43,44)$. IL-1 stimulates bone resorption and PG production in bone $(13,15-17,45,46)$. We recently reported that IL-1 increased PG production through the induction of PGHS-2 mRNA with less effect on PGHS-1 production or arachidonic acid release in cultured mouse calvariae (31) and in MC3T3-E1 cells (32). IL-1 has been shown to increase PGHS protein and mRNA and to activate PLA $_{2}$ in other cell types (47-52). A role for IL-1 in postmenopausal bone loss is supported by studies showing that both natural and surgical menopause are associated with increased production of IL-1 bioactivity in cultured monocytes and that this effect is reversed by estrogen replacement (19-22). Recently, in vivo administration of IL-1ra was found to inhibit bone loss in ovariectomized rats (53). In our study, although the differential stimulation of MSup on PGHS-2 and PGE 2 levels were blocked by IL-1ra and anti-IL- $1 \alpha$ antibodies, the concentrations of IL- $1 \alpha$ in MSups
Table VI. Quantitation of PGHS-2 and PGHS-1 mRNA Levels in Residual Tibiae of SHAM, OVX, and OVX+E Mice (Pooled from 12-13 Mice in Each Group) by Competitive RT-PCR

\begin{tabular}{lccc}
\hline \multicolumn{1}{c}{ Experiment No. } & 1 & 3 & Mean \pm SE \\
\hline PGHS-2 (sample/competitor) & & & \\
$5 \mu$ l of RT-PCR solution* & & & \\
SHAM & 0.76 & 0.64 & $0.70 \pm 0.06$ \\
OVX & 1.13 & 1.06 & $1.10 \pm 0.04^{\ddagger}$ \\
OVX+E & 0.91 & 1.04 & $0.98 \pm 0.07^{\ddagger}$ \\
10 $\mu$ l of RT-PCR solution & & & \\
SHAM & 1.58 & 1.48 & $1.53 \pm 0.05$ \\
OVX & 1.74 & 2.08 & $1.91 \pm 0.17^{8}$ \\
OVX+E & 1.66 & 2.28 & $1.97 \pm 0.31$ \\
PGHS-1 (sample/competitor) & & & \\
$2 \mu$ l of RT-PCR solution & & & \\
SHAM & 0.38 & 0.31 & $0.35 \pm 0.04$ \\
OVX & 0.39 & 0.30 & $0.35 \pm 0.05$ \\
OVX+E & 0.38 & 0.30 & $0.34 \pm 0.04$ \\
6 $\mu$ l of RT-PCR solution & & & \\
SHAM & 1.04 & 1.12 & $1.08 \pm 0.04$ \\
OVX & 1.07 & 1.25 & $1.16 \pm 0.09$ \\
OVX+E & 1.01 & 1.21 & $1.11 \pm 0.10$ \\
& & & \\
\hline
\end{tabular}

* 2- $\mu \mathrm{g}$ aliquots of total RNA were reverse-transcribed in final volume of $30 \mu \mathrm{l}$ of RT-PCR solution and two aliquots of the solution $(5 \mu \mathrm{l}$ and $10 \mu \mathrm{l}$ for PGHS-2; $2 \mu \mathrm{l}$ and $6 \mu \mathrm{l}$ for PGHS-1) were amplified with a fixed amount of cDNA competitor. Data were expressed as the intensity ratio of sample to competitor. Significant difference from SHAM: ${ }^{\ddagger} P$ $<0.01,{ }^{\S} P<0.05$.

and the mRNA levels of IL- $1 \alpha$ in bone marrow cells did not vary among SHAM, OVX, and OVX +E mice. Hence, mechanisms other than regulation of IL- $1 \alpha$ production by estrogen deficiency or replacement must be responsible. Possible explanations of this phenomenon include the presence of either inhibitors or stimulators of IL- $1 \alpha$ activity in MSup or the presence of other factors in MSup that enhance IL- $1 \alpha$ production by calvaria cultures. There might also be some factors in MSup from OVX mice that increase the responsiveness of cultured calvariae to cytokines.

There are several known stimulators and inhibitors of the PG-response of bone cultures to IL-1. One of these is IL-1ra, a member of IL-1 family. IL-1ra inhibits the action of IL-1 but does not transduce signals when bound to the IL-1 receptor (42, 43). IL-1ra can abrogate both IL-1-stimulated resorption and $\mathrm{PGE}_{2}$ production in bone cells $(4,41)$. However, we found that IL-1ra mRNA levels in marrow cells were not regulated by estrogen deficiency or replacement. Another natural inhibitor of IL-1 biologic activity is the soluble type II IL-1 receptor. Factors that synergistically increase the PG-responses of bone cells to IL-1 could also produce the effects that we observed. We have previously demonstrated that both TGF $\alpha(32,54)$ and TGF $\beta$ (55) synergistically enhance IL-1-stimulated PG synthesis in bone cells or bone cultures. We have also previously demonstrated that calvarial cultures produce IL-1 spontaneously and that the biologically active form of IL-1 in the conditioned medium from murine calvaria cultures is IL- $1 \alpha$ (44). It is possible that factors in MSups from OVX mice could induce greater de novo production of $\mathrm{IL}-1 \alpha$ in the calvarial cultures compared with MSups from SHAM or OVX+E. How- 
ever, IL- $1 \alpha$ levels in the conditioned culture media from calvariae treated with $20 \%$ MSup from experiments 2, 3, and 4 were measured by ELISA and were not significantly different among the three groups (data not shown).

Several cytokines other than IL-1 may be important in the bone loss that occurs with estrogen deficiency. IL- 6 production by bone cells or bone marrow cells is regulated by estrogen $(23,25)$ and may play an important role in the bone loss of estrogen deficiency (24). Moreover, knockout of the IL-6 gene in mice reduces bone loss after ovariectomy (56). IL-11 may also play a role in osteoclastogenesis (26). TNF-binding protein reduces the bone loss of ovariectomized rats (57). However, in this study, neutralizing antibodies against these cytokines did not reduce the differential effects of MSup from OVX mice on PGHS-2 expression and $\mathrm{PGE}_{2}$ production. Moreover, in preliminary studies, we found that while IL- $1 \alpha$, IL- $1 \beta$, and TNF $\alpha$ could induce PGHS-2 mRNA and increase $\mathrm{PGE}_{2}$ production in neonatal mouse calvarial cultures, IL-6 and IL-11 were ineffective (58).

There was no significant difference in the total number of marrow cells among SHAM, OVX, and OVX+E groups. However, in OVX animals, the percentage of lymphocytes was increased and the percentage of granulocytes was decreased significantly relative to SHAM $(P<0.01)$. It is possible that the changes in the number of these cells might have influenced the differences we observed in MSup activity on PGHS-2 and PGE $_{2}$ production.

The changes in medium $\mathrm{PGE}_{2}$ levels correlated with changes in PGHS-2 mRNA levels in the calvaria cultures but not with PGHS-1 or cPLA ${ }_{2}$ mRNA levels. Although cPLA $_{2}$ is thought to be the most important regulator of AA release, other enzymes may also be involved. These include secreted $\operatorname{PLA}_{2}\left(\mathrm{sPLA}_{2}\right)$, a family of 14-kD enzymes, including group I (pancreatic) and group II (synovial, platelet) sPLA . PLA $_{2}$ is an $85-\mathrm{kD} \mathrm{PLA}$, with no homology to the $14-\mathrm{kD}$ forms, which is selective for release of $\mathrm{AA}(59,60)$, while $\mathrm{SPLA}_{2}$ causes nonselective release of fatty acids from the sn-2 portion of phospholipids (61). In addition, the role of the "downstream" enzymes, which convert $\mathrm{PGH}_{2}$ to its different active products, is still to be determined. It has been postulated that these enzymes are not highly regulated, and this is consistent with our finding that $\mathrm{PGE}_{2}$ levels correlated with PGHS-2 mRNA levels.

A stimulatory effect of OVX on PGHS- 2 mRNA levels was seen in adult mouse residual tibiae in vivo, although to a much smaller degree than seen in neonatal mouse calvariae treated with MSup from OVX mice. However, estrogen replacement did not reverse this effect of OVX in vivo. This discrepancy between the effects in vivo and in vitro might be due to the kinetics of PGHS-2 induction. Induction of PGHS- 2 mRNA by many agents is transient despite the continuing presence of the inducing agents (30). The neonatal calvariae were acutely stimulated by MSups whereas the residual tibiae were chronically exposed to the factors in MSup.

An imbalance between resorption and formation rates appears to be the principal defect in postmenopausal osteoporosis. The effects of IL-1 on bone are multiple. It is a potent stimulator of resorption and inhibitor of formation. Our data indicate that estrogen deficiency may enhance the ability of bone cells to respond to IL-1 $\alpha$. We hypothesize that increases in the in vivo response of bone to locally produced IL-1 are involved in the effects of estrogen withdrawal on bone. The recent finding that IL-1ra administration to rats decreases the effects of ovariectomy on bone supports this hypothesis (53).
In the initial study by Miyaura et al., MSup from OVX mice was reported to stimulate bone resorption more than MSup from SHAM mice and this differential effect was blocked by indomethacin (10). Based on our data, we speculate that unknown factors in MSups regulate IL- $1 \alpha$ activity to produce the differential responses of bone cells. This in turn stimulates greater PG production in bone in response to OVX MSups, which increases bone resorption in estrogen deficiency. These observations support the concept that therapies which can inhibit the production or activity of IL-1 $\alpha$ in bone may be useful in reversing the effects of ovariectomy on bone mass (53).

\section{Acknowledgments}

We thank Dr. Chisato Miyaura, Showa University, Japan, for helpful discussion of experimental protocols. We also thank Ms. Olga Voznesensky, Cynthia Alander, and Pamela Fall at the University of Connecticut Health Center, and Ms. Yumiko Nagai and Dr. Hideyuki Yamato at Kureha Pharmaceutical Co., Tokyo, Japan, for their expert technical assistance.

This work was supported by grants AR18063, AR38933, AR41348, and AR42362 from the National Institutes of Health, and by funds from the Department of Veterans Affairs Merit Review Program.

\section{References}

1. Riggs, B. L., and L. J. Melton. 1986. Medical progress: involutional osteoporosis. N. Engl. J. Med. 314:1676-1684.

2. Slemenda, C., S. L. Hui, C. Longcope, and C. C. Johnston. 1987. Sex steroids and bone mass: a study of changes about the time of menopause. J. Clin. Invest. 80:261-269.

3. Lindsay, R., D. M. Hart, C. Forrest, and C. Baird. 1980. Prevention of spinal osteoporosis in oophorectomized woman. Lancet. ii:1151-1154.

4. Raisz, L. G., and T. J. Martin. 1983. Prostaglandins in bone and mineral metabolism. In Bone and Mineral Research, Annual 2. W. A. Peck, editor. Elsevier Science Publishing, Inc., New York. p. 286.

5. Harvey, W., and A. Bennett. 1988. Prostaglandins in bone resorption. CRC Press, Boca Raton, FL. p. 134.

6. Pilbeam, C. C., J. Klein-Nulend, and L. G. Raisz. 1989. Inhibition by $17 \beta-$ estradiol of PTH stimulated resorption and prostaglandin production in cultured neonatal mouse calvariae. Biochem. Biophys. Res. Commun. 163:1319-1324.

7. Feyen, J. H. M., and L. G. Raisz. 1987. Prostaglandin production from sham operated and oophorectomized rats: effect of $17 \beta$-estradiol in vivo. Endocrinology. 121:819-821.

8. Lane, N., T. Coble, and D. B. Kimmel. 1990. Effects of naproxen on cancellous bone in ovariectomized rats. J. Bone Miner. Res. 5:1029-1035.

9. Kimmel, D. B., T. Coble, and N. Lane. 1992. Long-term effect of naproxen on cancellous bone in ovariectomized rats. Bone (Tarrytown). 13:167-172.

10. Miyaura, C., K. Kusamo, T. Masuzawa, O. Chaki, Y. Onoue, M. Aoyagi, T. Sasaki, T. Tamura, Y. Koishihara, Y. Ohsugi, and T. Suda. 1995. Endogenous bone-resorbing factors in estrogen deficiency: cooperative effects of IL-1 and IL6. J. Bone Miner. Res. In press.

11. Rodan, S. B., G. A. Rodan, H. A. Simmons, R. W. Walenga, M. B. Feinstein, and L. G. Raisz. 1981. Bone resorptive factor produced by osteosarcoma cells with osteoblastic features is $\mathrm{PGE}_{2}$. Biochem. Biophys. Res. Commun 102:1358-1365.

12. Feyen, J. H. M., G. van der Wilt, P. Moonen, A. DiBon, and P. J. Nijiweide. 1984. Stimulation of arachidonic acid metabolism in primary cultures of osteoblast-like cells by hormones and drugs. Prostaglandins. 28:213-220.

13. Klein-Nulend, J., C. C. Pilbeam, J. R. Harrison, P. M. Fall, and L. G. Raisz. 1991. Mechanism of regulation of prostaglandin production by parathyroid hormone, interleukin-1, and cortisol in cultured mouse parietal bones. Endocrinology. 128:2503-2510.

14. Raisz, L. G., and H. A. Simmons. 1985. Effects of parathyroid hormone and cortisol on prostaglandin production by neonatal rat calvaria in vitro. Endocr. Res. 11:59-74.

15. Gowen, M., D. D. Wood, E. J. Ihrie, M. K. B. McGuire, and R. G. G. Russell. 1983. An interleukin-1 like factor stimulate bone resorption in vitro. Nature (Lond.). 306:378-380.

16. Sato, K., Y. Fujii, K. Kasono, M. Saji, T. Tsushima, and K. Shizume. 1986. Stimulation of prostaglandin $E_{2}$ and bone resorption by recombinant human interleukin- $1 \alpha$ in fetal long bone. Biochem. Biophys. Res. Commun. 143:618624.

17. Ikeda, E., M. Kusaka, Y. Hakeda, K. Yokota, M. Kumegawa, and S. 
Yamamoto. 1988. Effects of interleukin-1 $\beta$ on osteoblastic clone MC3T3-E1 cells. Calcif. Tissue Int. 43:162-166.

18. Tashjian, A. H., E. F. Voelkel, M. Lazzaro, F. R. Singer, A. B. Roberts, R. Derynck, M. E. Winkler, and L. Levine. 1985. $\alpha$ and $\beta$ human transforming growth factors stimulate prostaglandin production and bone resorption in cultured mouse calvaria. Proc. Natl. Acad. Sci. USA. 82:4535-4538.

19. Pacifici, R., L. Rifas, R. MacCracken, I. Vered, C. McMurtry, L. V. Avioli, and W. A. Peck. 1989. Ovarian steroid treatment blocks a postmenopausal increase in blood monocyte interleukin-1 release. Proc. Natl. Acad. Sci. USA. 86:23982402.

20. Pacifici, R., C. Brown, E. Puscheck, E. Friedrich, E. Slatopolsky, D. Maggio, R. MacCracken, and L. V. Avioli. 1991. Effects of surgical menopause and estrogen replacement on cytokine release from human blood mononuclear cells. Proc. Natl. Acad. Sci. USA. 88:5134-5138.

21. Pioli, G., G. Basini, M. Pefrazzoni, G. Musetti, V. Ulietti, D. Bresciani, P. Villa, A. Bacci, D. Hughes, G. Russel, and M. Passeri. 1992. Spontaneous release of interleukin-1 and interleukin- 6 by peripheral blood monocytes after ovariectomy. Clin. Sci. (Lond.). 83:503-507.

22. Matsuda, T., K. Matsui, Y. Shimakoshi, Y. Aida, and S. Hukuda. 1991. 1-hydroxyethilidene-1,1-bisphosphanate decreases the postovariectomy-enhanced interleukin-1 production by peritoneal macrophages in adult rats. Calcif. Tissue Int. 49:403-406.

23. Girasole, G., R. L. Jilka, G. Passeri, S. Boswell, G. Boder, D. C. Williams, and S. C. Manolagas. 1992. 17 $\beta$-estradiol inhibits interleukin- 6 production by bone marrow-derived stromal cells and osteoblasts in vitro: a potential mechanism for the antiosteoporotic effect of estrogens. J. Clin. Invest. 89:883-891.

24. Jilka, R. L., Hangoc, G. Girasole, G. Passeri, D. C. Williams, J. S. Abrams, B. Boyce, H. Broxmeyer, and S. C. Manolagas. 1992. Increased osteoclast development after estrogen loss: mediation by interleukin-6. Science (Wash. DC). 257:88-91.

25. Passeri, G., G. Girasole, R. L. Jilka, and S. C. Manolagas. 1993. Increased interleukin- 6 production by murine bone marrow and bone cells after estrogen withdrawal. Endocrinology. 133:822-828.

26. Girasole, G., G. Passeri, R. L. Jilka, and S. C. Manolagas. 1994. Interleukin-11: a new cytokine critical for osteoclast development. J. Clin. Invest. 93:1516-1524.

27. Ralston, S. H., R. G. G. Russel, and M. Gowen. 1990. Estrogen inhibits release of tumor necrosis factor from peripheral blood mononuclear cells in postmenopausal women. J. Bone Miner. Res. 5:983-988.

28. Smith, W. L. 1992. Prostanoid biosynthesis and mechanisms of action Am. J. Physiol. 263:F181-F191.

29. Kujubu, D. A., B. S. Fletcher, B. C. Varnum, R. W. Lim, and H. R. Herschman. 1991. TIS10, a phorbol ester tumor promoter-inducible mRNA from Swiss 3T3 cells, encodes a novel prostaglandin synthase/cyclooxygenase homologue. J. Biol. Chem. 266:12866-12872.

30. Pilbeam, C. C., H. Kawaguchi, Y. Hakeda, O. S. Voznesensky, C. B. Alander, and L. G. Raisz. 1993. Differential regulation of inducible and constitutive prostaglandin endoperoxide synthase in osteoblastic MC3T3-E1 cells. J. Biol. Chem. 268:25643-25649.

31. Kawaguchi, H., L. G. Raisz, O. S. Voznesensky, C. B. Alander, Y. Hakeda and C. C. Pilbeam. 1994. Regulation of the two prostaglandin G/H synthases by parathyroid hormone, interleukin-1, cortisol, and prostaglandin $\mathrm{E}_{2}$ in cultured neonatal mouse calvariae. Endocrinology. 135:1157-1164.

32. Harrison, J. R., J. A. Lorenzo, H. Kawaguchi, L. G. Raisz, and C. C. Pilbeam. 1994. Stimulation of prostaglandin $E_{2}$ production by interleukin- $1 \alpha$ and transforming growth factor- $\alpha$ in osteoblastic MC3T3-E1 cells. J. Bone Miner. Res. 9:817-823.

33. Kawaguchi, H., R. Yavari, M. L. Stover, D. W. Rowe, L. G. Raisz and C. C. Pilbeam. 1994. Measurement of interleukin-1 stimulated constitutive prostaglandin $\mathrm{G} / \mathrm{H}$ synthase (cyclooxygenase) mRNA levels in osteoblastic MC3T3-E1 cells using competitive reverse transcriptase polymerase chain reaction. Endocr. Res. 20:219-233.

34. Genovese, C., D. Rowe, and B. E. Kream. 1984. Construction of DNA sequences complementary to rat $\alpha 1$ and $\alpha 2$ collagen mRNA and their use in studying the regulation of type I collagen synthesis by 1,25-dihydroxyvitamin D. Biochemistry. 23:6210-6216.

35. Rogers, C. H. 1973. Blood sample preparation for automated differential systems. Am. J. Med. Technol. 39:435-438.

36. Li, C. Y., K. W. Lam, and L. T. Yam. 1973. Esterases in human leukocytes. J. Histochem. Cytochem. 21:1-12.

37. Fry, D. E., L. Pearlstein, R. L. Fulton, and H. C. Polh, Jr. 1980. Multiple system organ failure. Arch. Surg. 115:136-140.

38. Lee, Y., Y. Matsuoka, S. Matsuno, Y. Kubo, M. Sugiura, K. Yamauchi, and H. Okumura. 1992. Effects of estradiol on bone density of rat osteoporosis model using DEXA (in Japanese). Abstract for 1992 Japanese Bone Morphometry Meeting: 34. (Abstr.)

39. Chomczynski, P., and N. Sacchi. 1987. Single-step method of RNA isolation by acid guanidinium thiocyanate-phenol-chloroform extraction. Anal. Biochem. 162:156-159.

40. Chirgwin, J. M., A. E. Przybyla, R. J. MacDonald, and W. J. Rutter. 1979. Isolation of biologically active ribonucleic acid from sources enriched in ribonuclease. Biochemistry. 18:5294-5299.

41. Seckinger, P., J. Klein-Nulend, C. B. Alander, R. C. Thompson, J. M. Dayer, and L. G. Raisz. 1990. Natural and recombinant human IL-1 receptor antagonists block the effects of IL-1 on bone resorption and prostaglandin production. J. Immunol. 145:4181-4184.

42. Dinarello, C. A., and R. C. Thompson. 1991. Blocking IL-1: interleukin1 receptor antagonist in vivo and in vitro. Immunol. Today. 12:404-410.

43. Dinarello, C. A., and S. M. Wolff. 1993. The role of interleukin-1 in disease. N. Engl. J. Med. 328:106-113.

44. Lorenzo, J. A., S. L. Sousa, S. E. VanDenBrink-Webb, and J. H. Korn. 1990. Production of both interleukin- $1 \alpha$ and $-1 \beta$ by newborn mouse calvarial cultures. J. Bone Miner. Res. 5:77-83.

45. Garrett, I. R., and G. R. Mundy. 1989. Relationship between interleukin1 and prostaglandins in resorbing neonatal calvaria. J. Bone Miner. Res. 4:789794.

46. Boyce, B. F., T. B. Aufdemorte, I. R. Garrett, A. J. P. Yates, and G. R. Mundy. 1989. Effects of interleukin-1 on bone turnover in normal mice. Endocrinology. 125:1142-1150.

47. Maier, J. A., T. Hla, and T. Maciag. 1990. Cyclooxygenase is an immediate-early gene induced by interleukin-1 in human endothelial cells. J. Biol. Chem. 265:10805-10808.

48. Raz, A., A. Wyche, N. Siegel, and P. Needleman. 1988. Regulation of fibroblast cyclooxygenase synthesis by interleukin-1. J. Biol. Chem. 263:30223028 .

49. Ristimaki, A., S. Garfinkel, J. Wessendorf, T. Maciag, and Hla, T. 1994. Induction of cyclooxygenase- 2 by interleukin- $1 \alpha$ : evidence for post-transcriptional regulation. J. Biol. Chem. 269:11769-11775.

50. Burch, R. M., J. R. Connor, and J. Axelrod. 1988. Interleukin-1 amplifies receptor-mediated activation of phospholipase $\mathrm{A}_{2}$ in $3 \mathrm{~T} 3$ fibroblasts. Proc. Natl. Acad. Sci. USA. 85:6306-6309.

51. Nakazato, Y., M. S. Simonson, W. H. Herman, M. Konieczkowski, and J. R. Sedor. 1991. Interleukin- $\alpha$ stimulates prostaglandin biosynthesis in serumactivated mesangial cells by induction of a non-pancreatic (type II) phopholipase A . J. Biol. Chem. 266:14119-14127.

52. Lin, L. L., A. Y. Lin, and D. L. DeWitt. 1992. Interleukin-1 $\alpha$ induces the accumulation of cytosolic phospholipase $A_{2}$ and the release of prostaglandin $E_{2}$ in human fibroblasts. J. Biol. Chem. 267:23451-23454.

53. Kimble, R. B., J. L. Vannice, D. C. Bloedow, R. C. Thompson, W. Hopfer, V. T. Kung, C. Brownfield, and R. Pacifici. 1994. Interleukin-1 receptor antagonist decreases bone loss and bone resorption in ovariectomized rats. J. Clin. Invest. 93:1959-1967.

54. Lorenzo, J. A., S. L. Sousa, and M. Centrella. 1988. Interleukin-1 in combination with transforming growth factor- $\alpha$ produces enhanced bone resorption in vitro. Endocrinology. 123:2194-2200.

55. Marusic, A., J. F. Kalinowski, J. R. Harrison, M. Centrella, L. G. Raisz, and J. A. Lorenzo. 1991. Effects of transforming growth factor- $\beta$ and IL- $1 \alpha$ on prostaglandin synthesis in serum-deprived osteoblastic cells. J. Immunol. 146:2633-2638.

56. Poli, V., R. Balena, E. Fattori, A. Markatos, M. Yamamoto, H. Tanaka, G. Ciliberto, G. A. Rodan, and F. Costantini. 1994. Interleukin-6 deficient mice are protected from bone loss caused by estrogen depletion. EMBO (Eur. Mol. Biol. Organ.) J. 13:1189-1196.

57. Kitazawa, R., R. B. Kimble, J. L. Vannice, V. T. Kung, and R. Pacifici. 1994. Interleukin-1 receptor antagonist and tumor necrosis factor binding protein decrease osteoclast formation and bone resorption in ovariectomized mice. $J$. Clin. Invest. 94:2397-2406.

58. Kawaguchi, H., L. G. Raisz, C. B. Alander, O. Voznesensky, and C. C. Pilbeam. 1994. Regulation of the prostaglandin production and bone resorption by interleukin-4 (IL-4) in cultured mouse calvariae. J. Bone Miner. Res. 9(Suppl. 1):S263. (Abstr.)

59. Clark, J. D., L.-L. Lin, R. W. Kriz, C. S. Ramesha, L. A. Sultzman, A. Y. Lin, N. Milona, and J. L. Knopf. 1991. A novel arachidonic acid-selective cytosolic $\mathrm{PLA}_{2}$ contains a $\mathrm{Ca}^{2+}$-dependent translocation domain with homology to PKC and GAP. Cell. 65:1043-1051.

60. Lin, L.-L., A. Y. Lin, and J. L. Knopf. 1992. Cytosolic phospholipase $A_{2}$ is coupled to hormonally regulated release of arachidonic acid. Proc. Natl. Acad. Sci. USA. 89:6147-6151.

61. Mayer, R. J., and L. A. Marshall. 1993. New insights on mammalian phospholipase $A_{2}(s)$; comparison of arachidonoyl-selective and -nonselective enzymes. FASEB (Fed. Am. Soc. Exp. Biol.) J. 7:339-348. 